\title{
Taking good care of myself
}

\section{Someone to watch over me.}

\section{Ian R. MacLeod}

The social worker came a day or so before I arrived. He was as briskly pleasant as the occasion, which I'd long been dreading, allowed. He was dressed bizarrely, but people from the future always are.

"We'll need to send a few helpful machines back with you," he murmured as he inspected our spare bedroom and the bathroom and then the kitchen, which no doubt looked ridiculously primitive to him. ${ }^{\alpha} \mathrm{But}$ nothing that'll get in your way."

Helen was equally reassuring when she came home that evening. "It's a tremendous challenge," she told me. "You always say you like challenges."

"I mean stufflike dimbing, hang-gliding, pushing things to the edge, not looking after some senile version of myself."

"Josh." She gave me one of her looks. "You have no choice"

She was right — and there was plenty of space in our nice house. It was as if we'd always planned on doing precisely this, although I hated the very thought.

I arrived a couple of mornings after, flanked by swish-looking machines, although I was just as pale and dithery as I'd feared. The creature I'd eventually become couldn't walk, could barely see, and certainly didn't comprehend what was happening to him. Exactly how long, I wondered (and secretly hoped), can I possibly last like this?

Scampering around our house like chromium shadows, the machines performed many of the more obvious and unpleasant duties, but much was still expected of me. I had to sit and talk, although my elderly self rarely said anything in response, and none of it was coherent. I also had to help myself eat, and wipe away the spilled drool afterwards. I had to hold my own withered hand.

"Do you remember this house - I mean, you must have lived here?"

But I was much too far gone to understand. Not, perhaps, in a vegetative state yet, but stale meat at very best.

Sometimes, I took me out, pretending to push the clever chair which was in fact more than capable of doing everything except getting rid of this cadaverous ghost - by itself. My work suffered. So did my relationship with Helen. I joined a selfhelp group. I sat in meeting halls filled with other unfortunates whod had the care of their future selves foisted on them. We debated in slow circles why our future children,

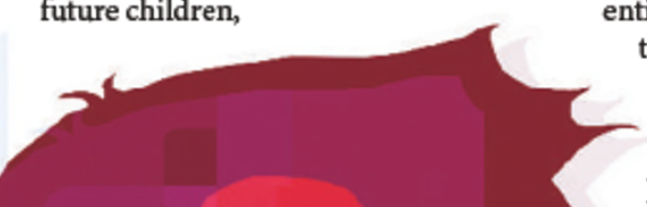

They fed me fresh blood, fresh air. I doubted if this husk I'd become was conscious of any presence other than its own dim existence now, but still I found myself sitting beside me, and talking endlessly about things I couldn't remember afterwards. It was as if I was trapped in a trance, or that part of me was dying as well. I lay entirely naked now under clever sheets that cleaned themselves. Occasionally, inevitably, I would lift them up, and breathe the stale air of my own mortality, and study the thin limbs and puckered flesh of what I would eventually become. The death itself was surprisingly easy. The machines saw to it that there was no pain, and I was there; I made sure I didn't die alone. A faint rattle, a tiny spasm. You're left wondering what all the fuss is about.

After the funeral, which of course I also had to arrange myself, and was far more poorly attended than I might have hoped, and then the scattering of my ashes at the windy lip of one of $\mathrm{my}$ favourite climbs, I looked around at my life like a sleeper awakening. Helen had left me, although quietly, without fuss. My house felt empty, but I knew that it was more to do with that old man than with her. I'm back to climbing regularly now. I'm back to freefall and hang-gliding. I find that I enjoy these sports, and many other kinds of dangerous and challenging physical activities, even more. After all, I know they can't kill me, and that the last phase of my life really isn't so very bad. But things have changed, for all that, and I still sometimes find myself sitting alone in my spare bedroom gazing at the taut sheets of that empty bed, although I and all those future machines have long gone. The sad fact is, I miss myself dreadfully, now that I'm no longer here.

lan R. MacLeod's latest novel, The House of

Storms, is just out in paperback, and a short-story collection, Past Magic, will also be published shortly. He's just completed a new novel, Song of Time, which looks back at this current century through the eyes of elderly woman contemplating a leap into virtual intelligence. He lives in the river town of Bewdley. dled in steel pipes and crystal insertions
I declined. The machines, with a will of their own, grew yet more sophisticated and crouched permanently beside me as I dled in steel pipes and crystal insertions. 